\title{
BADANIA KOMPOZYTOWEGO SIŁOWNIKA HYDRAULICZNEGO DO SERWOMECHANIZMU WSPOMAGANIA STEROWANIA ŚMIGEOWCEM BEZZAŁOGOWYM
}

\author{
PAWEe SzcZePAniak, GrZegorz JastrzęBSki \\ Instytut Techniczny Wojsk Lotniczych, Warszawa \\ e-mail: pawel.szczepaniak@itwl.pl; grzegorz.jastrzebski@itwl.pl
}

Przedstawione w publikacji zagadnienia dotyczą opracowania autorskiej technologii i wykonania siłownika hydraulicznego do napędu hydraulicznego układu sterowania lekkim śmigłowcem bezzałogowym. Celem pracy jest przedstawienie zagadnień dotyczących projektowania siłownika hydraulicznego do układu sterowania skokiem ogólnym i okresowym głowicy wirnika nośnego oraz skokiem śmigła ogonowego. W artykule przedstawiono autorskie rozwiązanie siłownika hydraulicznego z centralnym zasilaniem. Projekt tego siłownika jest elementem składowym projektu wielozadaniowego lekkiego śmigłowca bezzałogowego. W artykule zaprezentowano propozycje zredukowania masy siłownika hydraulicznego przez wprowadzenie nowoczesnych technik kompozytowych. Przeprowadzone prace projektowe i wyniki przeprowadzonych badań prototypu siłownika hydraulicznego ze wzmocnieniami kompozytowymi pozwoliły sformułować wnioski dotyczące procesu projektowania takich siłowników dedykowanych m.in. dla lekkich śmigłowców bezzałogowych.

Stowa kluczowe: napęd hydrauliczny, układ sterowania, siłownik kompozytowy

\section{Wstęp}

Siłownik hydrauliczny jest silnikiem liniowym przetwarzającym energię ciśnienia cieczy roboczej w energię mechaniczną ruchu prostoliniowo-zwrotnego. Energia ta przekazywana jest urządzeniom za pomocą tłoczyska, nurnika lub innego urządzenia. Głównym elementem roboczym w siłownikach jest tłok osadzony na tłoczysku lub nurnik, na który działa ciśnienie cieczy roboczej, wywołując siłę użyteczną, pokonującą obciążenia w postaci sił zewnętrznych. Na rysunku 1 zaprezentowano typowy siłownik hydrauliczny z opisem najważniejszych elementów składowych. Siłownik jest po pompie drugim co do ważności elementem układu hydraulicznego. Zadaniem siłownika jest pokonywanie obciążeń oraz realizowanie ruchów z wymaganymi prędkościami. Cylindry hydrauliczne zwykle wykonuje się jako odlewy żeliwne albo z rur stalowych grubościennych. Ze względu na trudności otrzymania szczelnego odlewu zwykle wykonuje się cylindry stalowe, zwłaszcza o dużej długości. Wymiary rur na cylindry dobiera się według znormalizowanych wymiarów. Wybiera się rury stalowe bez szwu walcowane lub ciągnione na zimno albo rury stalowe bez szwu walcowane na gorąco. Stal o twardości mniejszej od $180 \mathrm{HB}$, nie nadaje się na cylindry ze względu na łatwość uszkodzenia gładzi cylindrycznej oraz możliwość powstawania zatarć. Kołnierze do przykręcania pokryw cylindra lub bezpośrednio te pokrywy mocuje się do rury przeważnie za pomocą gwintu zewnętrznego na rurze, rzadziej za pomocą gwintu wewnętrznego lub przez przyspawanie. Stosuje się także oparcie kołnierza na dzielonym pierścieniu osadzonym w wytoczeniu rury lub ściągnięcie pokryw długimi śrubami przechodzącymi wzdłuż cylindra. Na rys. 2 przedstawiono w ujęciu klasyfikacyjnym różne rodzaje i typy siłowników hydraulicznych.

W budowie siłowników spotyka się wiele rozwiązań konstrukcyjnych mocowania pokryw do cylindra oraz mocowania siłowników do elementów nośnych lub korpusów układów napędzanych [PN-84/M-73220]. 


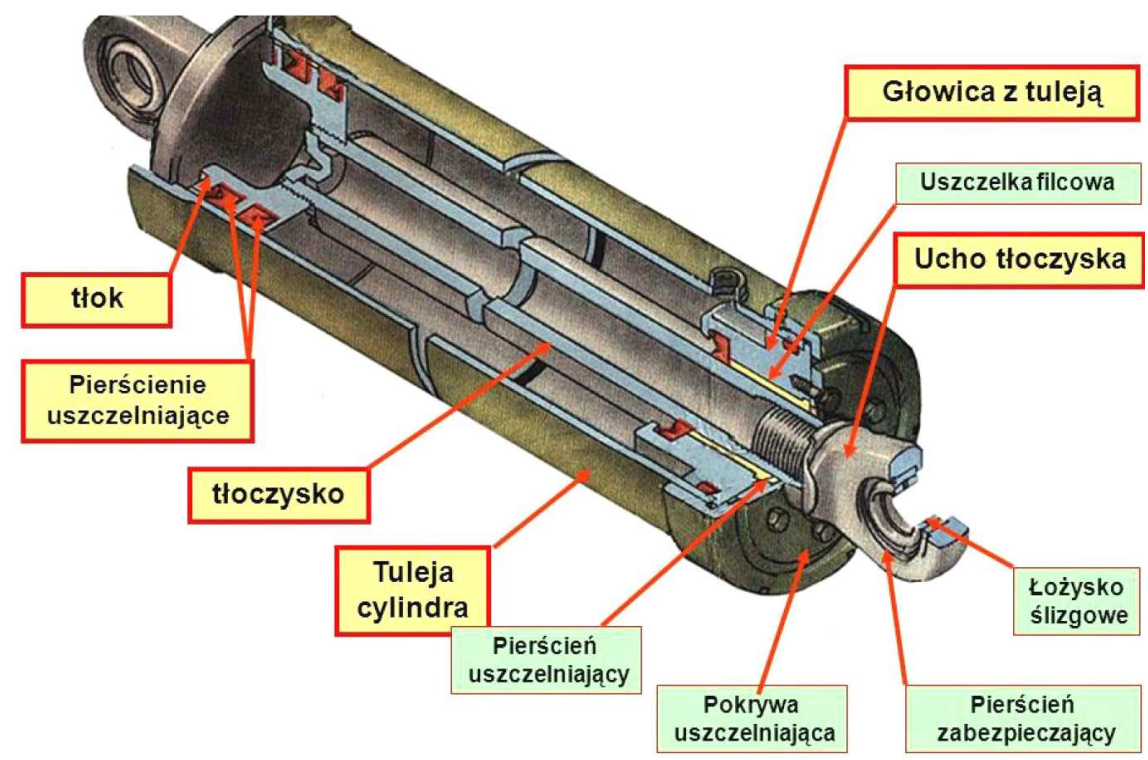

Rys. 1. Siłownik hydrauliczny z oznaczonymi elementami składowymi

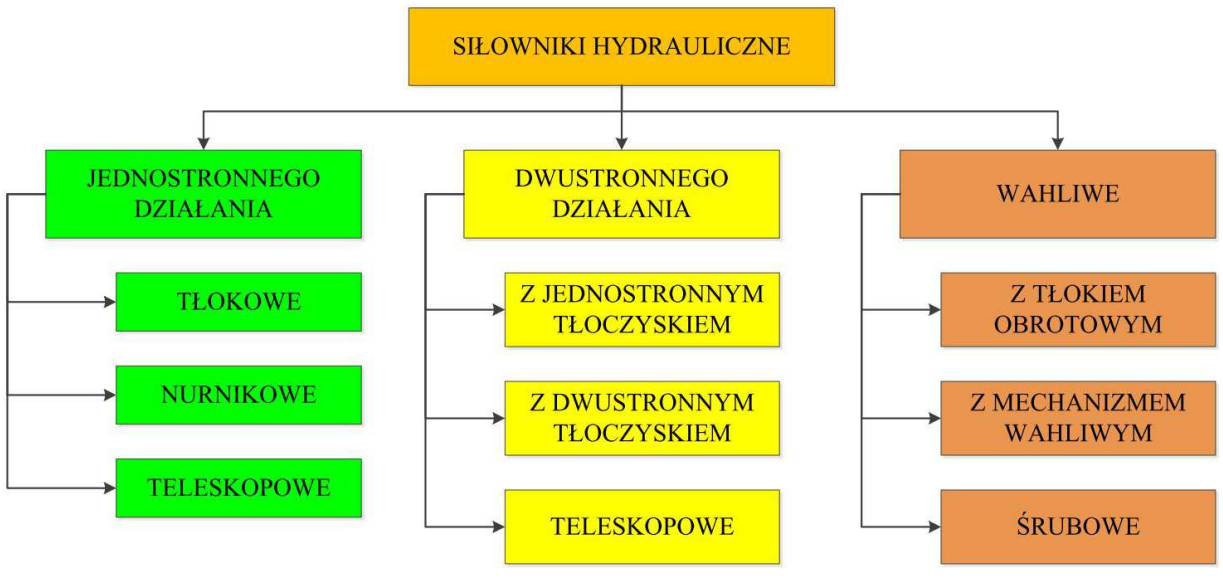

Rys. 2. Klasyfikacja siłowników hydraulicznych [PN-73/M-73004]

Najczęstsze sposoby mocowania pokryw do cylindrów:

- skręcenie całości (dwóch pokryw z cylindrem) czterema śrubami,

- przyspawanie pokrywy tylnej oraz gwintowe połączenie pokrywy przedniej z cylindrem,

- połączenie gwintowe obu pokryw z cylindrem.

Zadaniem siłownika jest pokonywanie obciążeń oraz realizowanie ruchów z wymaganymi prędkościami. Dla nowoprojektowanego siłownika należy określić:

- wartości sił zewnętrznych pokonywanych przez tłok $\left(P_{c}\right)$,

- wartości prędkości ruchów posuwisto-zwrotnych tłoka $(v)$,

- długość drogi przesuwu (skok) tłoka $\left(H_{c}\right)$,

- ciśnienie pracy siłownika,

- sposób mocowania z elementami nośnymi napędzanych maszyn i urządzeń,

- warunki pracy siłownika.

Doboru geometrii siłownika dokonuje się, zakładając obciążenie zewnętrzne siłownika $P_{c}[\mathrm{~N}]$ oraz ciśnienie nominalne pompy $p_{3}[\mathrm{~Pa}]$. Powierzchnię roboczą tłoka $F\left[,^{2}\right]$ oblicza się ze wzoru

$$
F\left(F_{1}\right)=\frac{P_{c}}{p_{3}}
$$


W zależności od zwrotu siły obciążającej siłownik z tłoczyskiem jednostronnym, powierzchnią robocza jest powierzchnia tłoka $F$ przy ruchu wysuwowym lub powierzchnia pierścieniowa tłoka $F_{1}$ przy ruchu powrotnym. Następnie w oparciu o wyznaczone wartości powierzchni tłoka $F$ lub $F_{1}$ oblicza się (ze wzorów na pole koła lub pierścienia) średnicę tłoka $D$ oraz średnicę tłoczyska $d$, które po zaokrągleniu do wartości znormalizowanych stanowią podstawowe dane techniczne w doborze siłownika z katalogów producentów elementów hydrauliki siłowej.

Przy ściskaniu siłowników długich odpowiednio zamocowanych o małym przekroju poprzecznym tłoczyska w stosunku do długości, tzw. smukłych, może wystąpić zjawisko wyboczenia. Polega ono na utracie stateczności (wygięciu siłownika) przy wzroście obciążenia zewnętrznego powyżej krytycznego. Zatem na etapie doboru siłowników z tłoczyskami smukłymi obciążonymi znacznymi siłami ściskającymi należy dokonać obliczeń sprawdzających na wyboczenie [1]-[3].

Przy ostatecznym katalogowym doborze siłowników decydują najważniejsze dane techniczne, do których zalicza się: ciśnienie nominalne, średnice tłoka i tłoczyska, skok tłoka, rodzaj cieczy, lepkość nominalną cieczy, dokładność filtracji, sposób mocowania.

Przy wyborze mocowania siłownika do konstrukcji maszyn lub urządzeń należy pamiętać o rozszerzalności cieplnej elementów siłownika pod wpływem wzrostu temperatury czynnika roboczego. Cylindry siłowników należy mocować w sposób dający swobodę wydłużeń cieplnych, bez wystąpienia niebezpiecznych (niszczących) naprężeń termicznych.

Dla dobranego siłownika należy obliczyć prędkości wysuwu $v[\mathrm{~m} / \mathrm{s}]$ oraz wsuwania się tłoczyska, przy zasilaniu siłownika strumieniem $Q_{c}\left[\mathrm{~m}^{3} / \mathrm{s}\right]$, równym nominalnej wydajności pompy z wzoru

$$
v=\frac{Q_{C}}{F\left(F_{1}\right)}
$$

\section{Siłowniki hydrauliczne $\mathrm{z}$ elementami kompozytów węglowych}

Prekursorem rozwoju siłowników hydraulicznych z elementami kompozytowymi jest firma Parker Hanifin, która jest potentatem światowym w zakresie hydrauliki siłowej. Parker Hanifin produkuje elementy hydrauliki siłowej dla wszystkich gałęzi przemysłu, również dla lotnictwa. Większość zespołów hydraulicznych we współczesnych samolotach, zarówno cywilnych jak i wojskowych, jest produkcji Parkera.

Siłowniki kompozytowe są pewnego rodzaju nowością na rynku, komercyjnie pojawiły się zaledwie kilka lat temu [8]. Elementem siłownika, który Parker wykonuje z kompozytu, to cylinder siłownika - jest to opatentowany specjalny kompozyt. Według deklaracji producenta gęstość tego kompozytu wynosi $1,6 \mathrm{~g} / \mathrm{cm}^{3}$, przy gęstości stopu konstrukcyjnego aluminium na poziomie $2,8 \mathrm{~g} / \mathrm{cm}^{3}$, stali $7,85 \mathrm{~g} / \mathrm{cm}^{3}$. Według deklaracji producenta wytrzymałość na rozciąganie tego kompozytu wynosi więcej niż $1000 \mathrm{MPa}$ (stopu konstrukcyjnego aluminium około $500 \mathrm{MPa}$, stali na siłowniki $550 \mathrm{MPa}$ ), to jest prawie dwukrotnie więcej, a także charakteryzuje się lepszą odpornością na obciążenia zmęczeniowe oraz odpornością korozyjną. Do budowy tego kompozytu producent deklaruje użycie włókien węglowych, szklanych, aramidowych oraz żywic epoksydowych. Do budowy cylindrów wykorzystywana jest cienkościenna tuleja stalowa lub ze stopów aluminium wzmocniona z zewnątrz materiałami kompozytowymi, których zadaniem jest zwiększenie odporności elementu na naprężenia obwodowe [8], [9].

Parker proponuje realizację elementów kompozytowych w trzech wariantach pokazanych na rys. 3 .

Kompozytowe siłowniki węglowe pojawiły się w sprzęcie do sportów wodnych (rys. 4), są to jednak siłowniki o znacznych rozmiarach - tu średnice $80 \div 200 \mathrm{~mm}$.

Wysokociśnieniowe produkty hydrauliczne wymagają elementów konstrukcyjnych o wysokiej wytrzymałości. Tradycyjnie produkty do typowych zastosowań przemysłowych oraz pojazdów 
(a)

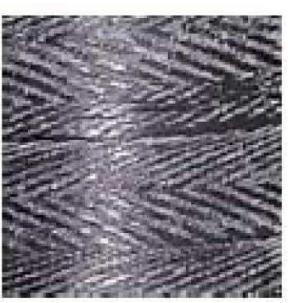

(b)

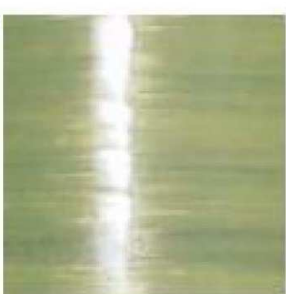

(c)

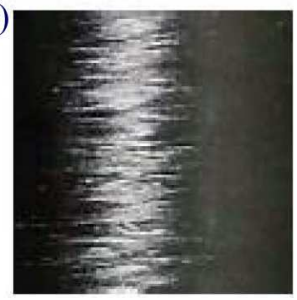

Rys. 3. Rodzaje kompozytów Parkera: (a) standard, (b) odporny na ścieranie z włóknami aramidowymi, ktore są odporne na trudne warunki, (c) wygląd zewnętrzny według oczekiwań klienta [8]

(a)

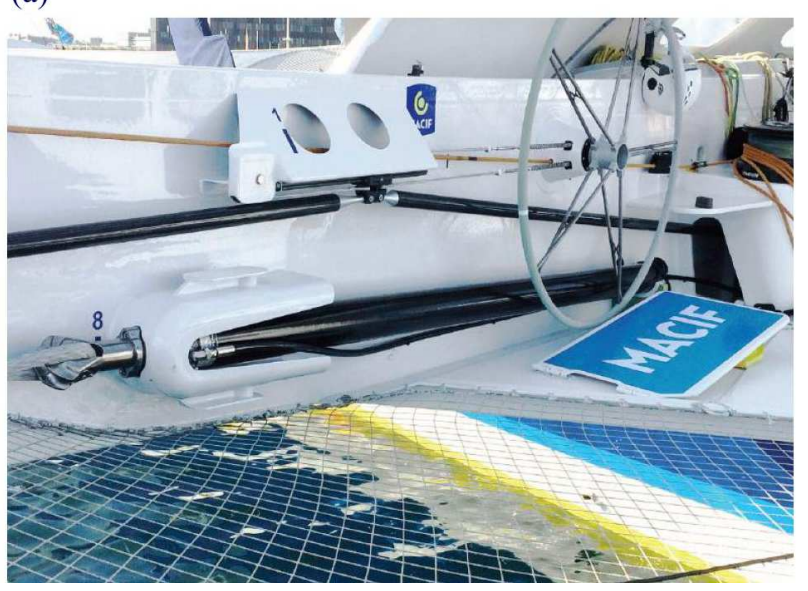

(b)
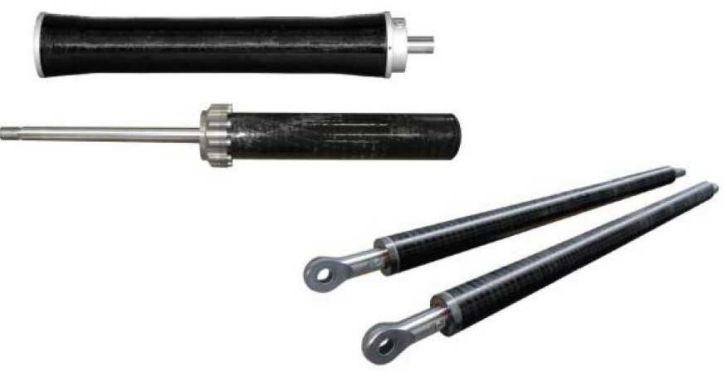

Rys. 4. Siłownik kompozytowy w sportach wodnych: (a) zabudowany na obiekcie, (b) widok ogólny [8]

i maszyn są wytwarzane ze stali o wysokiej wytrzymałości, natomiast w zastosowaniach wymagających zmniejszenia masy używa się droższych stopów o mniejszej masie właściwej. Wprowadzenie materiałów kompozytowych z włókna węglowego otwiera nowe możliwości w zakresie projektowania lekkich elementów o wysokiej wytrzymałości. Tradycyjnie w produktach kompozytowych wykorzystuje się materiały kompozytowe w celu wzmocnienia konstrukcji i obniżenia masy elementów stalowych. Seria produktów Lightraulics firmy Parker obejmuje klasyczne produkty kompozytowe, jak również produkty z tulejami cylindrowymi wykonanymi w całości z materiałów kompozytowych. Firma Parker, dzięki wieloletniemu doświadczeniu w zakresie rozwoju materiałów kompozytowych, projektuje lekkie siłowniki i akumulatory hydrauliczne dla szerokiego zakresu zastosowań od 1996 roku (informacje producenta, wg autorów komercyjnie pojawiły się zaledwie kilka lat temu). Produkty Lightraulics ${ }^{\circledR}$ oferują znaczną redukcję masy, a jednocześnie zapewniają wyjątkową wytrzymałość na zmęczenie oraz na rozrywanie. Standardowy asortyment siłowników, przetestowany w milionach cykli, jest zaprojektowany dla ciśnień roboczych do 380 bar. Ponadto firma Parker oferuje niestandardowe konstrukcje o ciśnieniu roboczym do 700 bar, które są dostępne na zamówienie (źródło: katalog Parker [8]). Dzięki opatentowanym technologiom kompozytowym zastosowanym w produktach Lightraulics ${ }^{\circledR}$ firma Parker może oferować ultralekkie produkty hydrauliczne o wysokich właściwościach użytkowych. W produktach kompozytowych firmy Parker wykorzystywane są systemy polimerów wzmocnionych specjalnie wybranymi włóknami, co pozwalana dostosować właściwości materiału przez odpowiednie zestawienie różnych włókien i spoiw [8].

Zastosowana technologia pozwala na znaczną redukcje masy siłownika w przypadku siłowników o stosunkowo dużych średnicach, tj. z zakresu $80 \div 200 \mathrm{~mm}$. Według deklaracji producenta redukcja masy siłownika w zależności od wybranej technologii Parkera wynosi maksymalnie $60 \%$. 
Siłowników o średnicy mniejszej niż $80 \mathrm{~mm}$ do zastosowań typowo lotniczych Parker nie proponuje [8], [9].
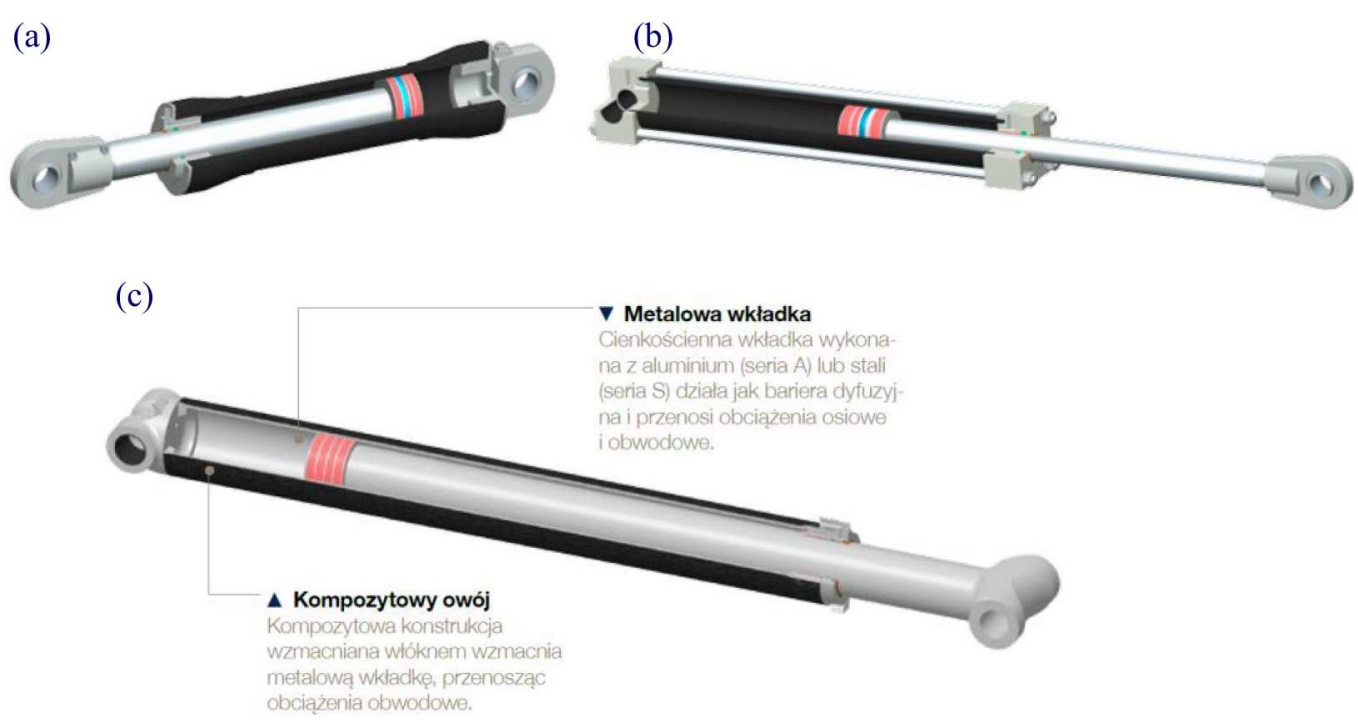

Rys. 5. Siłownik kompozytowy: (a) - serii C (tuleja cylindra wykonana w całości z materiału

kompozytowego), (b) - serii T (całość z materiału kompozytowego z prętami ściągającymi),

(c) - serii A i S (cienkościenna tuleja wykonana ze stali lub aluminium i wzmocniona kompozytami [8])

\section{Siłownik dwutłokowy kompozytowy z centralnym zasilaniem}

W ITWL w ramach poszukiwania nowoczesnych napędów hydraulicznych o niskiej masie własnej opracowano autorskie rozwiązanie siłownika hydraulicznego z centralnym zasilaniem o nazwie SHDTLK. W tym rozwiązaniu zaproponowano nowoczesne technologie kompozytowe do wzmocnienia kluczowych elementów. Doboru materiałów konstrukcyjnych na elementy składowe siłownika dokonano w oparciu o stopy metali lekkich, spełniających kryteria wytrzymałościowe. Dodatkowo tuleje cylindrów z przeznaczeniem do wzmocnienia kompozytowego wykonano z typowego materiału przy minimalnej grubości.

Na rys. 6a i 6b zaprezentowano model opracowanego siłownika SHDTLK w rzucie aksonometrycznym. Parametrami wyjściowymi przy budowie modelu bryłowego były:

- maksymalny skok roboczy: $70 \mathrm{~mm}$,

- obciążenie eksploatacyjne: $750 \mathrm{~kg}$,

- średnica wewnętrzna cylindra: $30 \mathrm{~mm}$.

Prototyp siłownika wykonanego w oparciu o opracowany model siłownika SHDTLK z wykonanym wzmocnieniem kompozytowym cylindra przedstawiono na rys. 6c.

W celu obniżania ciężaru napędu hydraulicznego w statkach powietrznych o przeznaczeniu wojskowym powinno stosować się instalacje o wysokiej wartości ciśnienia roboczego [6]. Układy projektowane na wysokie wartości ciśnienia roboczego (powyżej $25 \mathrm{MPa}$ ) są szczególnie wrażliwe na warunki eksploatacyjne i wymagają większej dokładności wykonania. Wiąże się to ze wzrostem wymagań dla cieczy roboczej i jej czystości (klasy czystości cieczy roboczej wg NAS 1638 lub PN ISO 4406) [9].

Elementy wykonawcze wraz ze zwiększaniem ciśnienia roboczego są mniejsze (przy uzyskiwanej tej samej sile potrzebnej do sterowania), natomiast wzrasta masa armatury i przewodów lub konieczne jest stosowanie nieporównywalnie droższych technologii wykonania i materiałów na te elementy. Istotny problem praktyczny stanowi również dostępność części. Przykładowo, zastosowanie zaworu o dopuszczalnym ciśnieniu pracy wynoszącym $20 \mathrm{MPa}$ w instalacji, która jest 
(a)

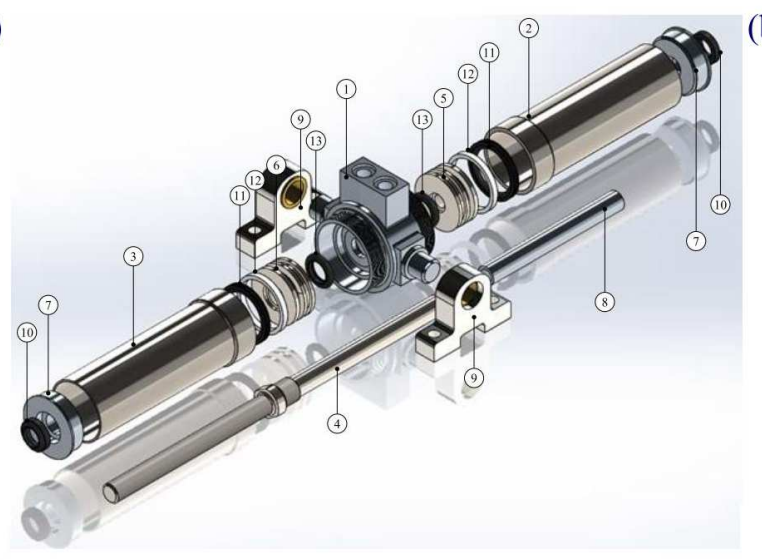

(b)

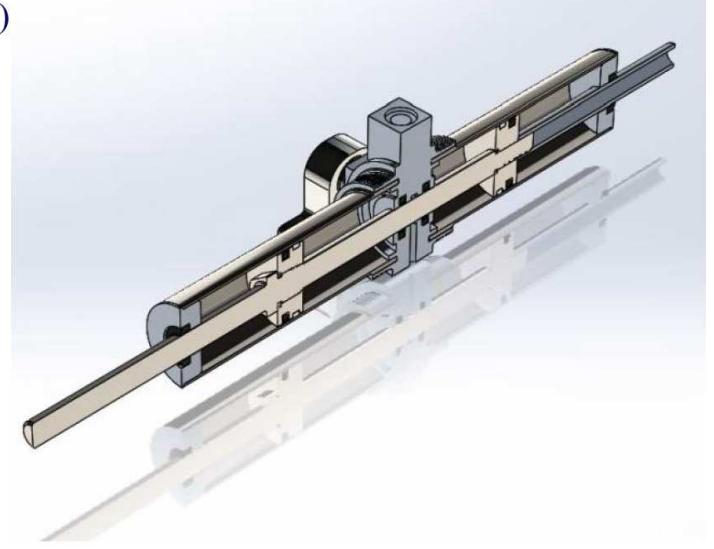

(c)

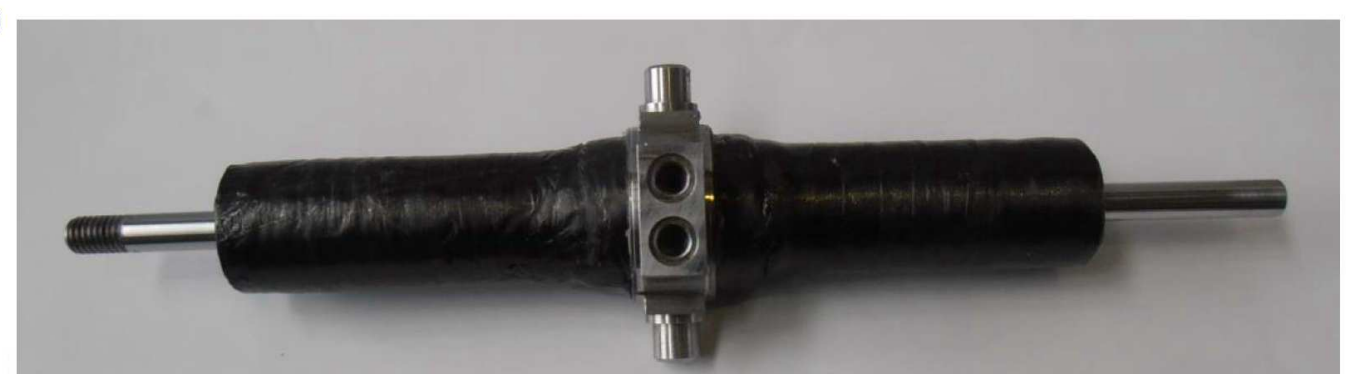

Rys. 6. Siłownik SHDTLK: (a) w rzucie aksonometrycznym (1 - mocowanie, 2 - cylinder 1 ,

3 - cylinder 2, 4-tłoczysko, 5 - tłok 1,6 - tłok 2, 7 - pokrywa, 8 - tuleja pomiarowa, 9 - podpora, 10 - pierścień zgarniający, 11 - uszczelka tłoka, 12 - pierścień prowadzący, 13 - uszczelnienie tłoczyska,

(b) przekrój podłużny, (c) prototyp siłownika SHDTLK ze wzmocnieniem z rowingu HTS 1600TEX i żywicy LH 289

projektowana na $15 \mathrm{MPa}$, jest działaniem nieracjonalnym według kryterium masy napędu hydraulicznego, natomiast z punktu widzenia dostępności elementów takie działanie jest jedynym rozsądnym. Możliwe jest zaprojektowanie i wykonanie takiego elementu dla danego zastosowania, co jest jednak zbyt kosztowne i nieuzasadnione ekonomicznie. Maksymalne wartości sił potrzebne do sterowania związane są obciążeniami płaszczyzn aerodynamicznych łopat wirnika nośnego oraz rozwiązaniami kinematyki układu sterowania łopatami, z których wynika również całkowity skok roboczy tłoczyska siłowników. Zakładana wartość prędkości ruchu tłoczyska związana jest z wymaganą dynamiką sterowania. Od zakładanej prędkości ruchu elementów wykonawczych napędu zależy zapotrzebowanie układu na strumień płynu hydraulicznego. Natomiast od siły potrzebnej do sterowania łopatami zależy ciśnienie robocze w układzie i pole powierzchni czynnej w siłowniku hydraulicznym [1], [3], [6], [7].

\section{Obliczenia konstrukcyjne}

W ramach realizacji zadania polegającego na określeniu poziomu naprężeń w tulei cylindra siłownika hydraulicznego SHDTLK w przedmiotowej pracy opisano podjęte próby modelowania wytrzymałości cylindra siłownika hydraulicznego z uwzględnieniem stosowania technik kompozytowych. Do badań symulacyjnych wykorzystano dodatek Simulation do oprogramowania SolidWorks. Na rysunku 7 przedstawiono widok zamocowanego i obciążonego modelu tulei cylindra siłownika ze stopu 7075 ze wzmocnieniem z kompozytu węglowego CFRP w postaci maty węglowej na osnowie z żywicy. Właściwości tego kompozytu przyjęto jako izotropowe (zgodnie z danymi literaturowymi). Oczywiście właściwości mechaniczne takiego kompozytu są znacznie gorsze (nawet o 100\%) niż dla kompozytów anizotropowych, zorientowanych kierunkowo. 


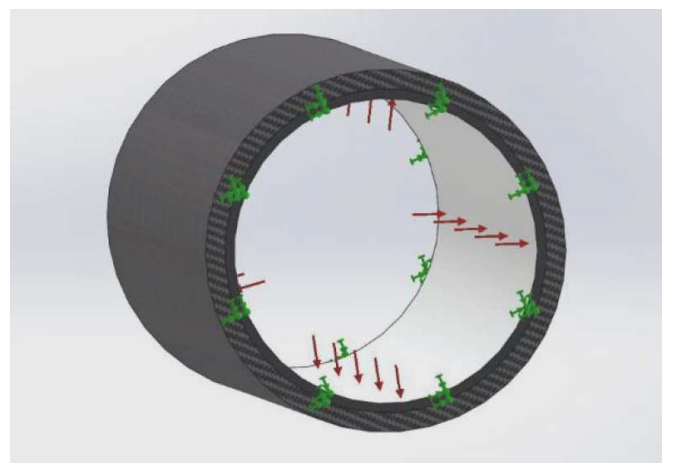

Rys. 7. Widok zamocowanego i obciążonego modelu tulei cylindra siłownika ze stopu 7075 ze wzmocnieniem z kompozytu węglowego CFRP

Tabela 1. Właściwości modelowanego kompozytu węglowego (dane literaturowe)

\begin{tabular}{|l|l|}
\hline Nazwa & CFRP \\
\hline Typ modelu & liniowy, izotropowy \\
\hline Granica plastyczności & $4 \mathrm{e}+008 \mathrm{~N} / \mathrm{m}^{2}$ \\
\hline Wytrzymałość na rozciąganie & $6.25 \mathrm{e}+008 \mathrm{~N} / \mathrm{m}^{2}$ \\
\hline Wytrzymałość na ściskanie & $5 \mathrm{e}+008 \mathrm{~N} / \mathrm{m}^{2}$ \\
\hline Współczynnik sprężystości wzdłużnej & $5 \mathrm{e}+009 \mathrm{~N} / \mathrm{m}^{2}$ \\
\hline Współczynnik Poissona & 0.263 \\
\hline Masa właściwa & $1530 \mathrm{~kg} / \mathrm{m}^{3}$ \\
\hline Współczynnik sprężystości poprzecznej & $5 \mathrm{e}+008 \mathrm{~N} / \mathrm{m}^{2}$ \\
\hline
\end{tabular}

Część metalową cylindra modelowano jako wykonaną ze stopu aluminium 7075 (odpowiednik lotniczego stopu dural PA-7), który charakteryzuje się znakomitymi właściwościami wytrzymałościowymi i może być wykorzystywany do budowy elementów lotniczych siłowników hydraulicznych. Właściwości mechaniczne stopu 7075 przedstawiono w tabeli 2. W warunkach symulacji określono połączenie elementów metalowego i kompozytowego spoiwem o bardzo małej, pomijalnej grubości, całkowicie odpornym na ścinanie - właściwości mechaniczne skleiny i jej wytrzymałość mechaniczna nie były brane pod uwage podczas badań.

Tabela 2. Właściwości modelowanego stopu 7075 (dane baza SolidWorks)

\begin{tabular}{|l|l|}
\hline Nazwa & 7075 (dural PA-7) \\
\hline Typ modelu & liniowy, izotropowy \\
\hline Granica plastyczności & $5.05 \mathrm{e}+008 \mathrm{~N} / \mathrm{m}^{2}$ \\
\hline Wytrzymałość na rozciąganie & $6.25 \mathrm{e}+008 \mathrm{~N} / \mathrm{m}^{2}$ \\
\hline Współczynnik sprężystości wzdłużnej & $7.2 \mathrm{e}+010 \mathrm{~N} / \mathrm{m}^{2}$ \\
\hline Współczynnik Poissona & 0.33 \\
\hline Masa właściwa & $2810 \mathrm{~kg} / \mathrm{m}^{3}$ \\
\hline Współczynnik sprężystości poprzecznej & $2.69 \mathrm{e}+010 \mathrm{~N} / \mathrm{m}^{2}$ \\
\hline
\end{tabular}

Na rysunku 8 przedstawiono wykres naprężeń zredukowanych obliczonych wg hipotezy Hubera-Misesa dla modelu tulei cylindra siłownika ze stopu 7075 ze wzmocnieniem wykonanym z izotropowego kompozytu węglowego w postaci mat na osnowie żywicy.

Wartość naprężeń wewnątrz cylindra na powierzchni obciążonej bezpośrednio nie przekracza $300 \mathrm{MPa}$. Na powierzchni zewnętrznej wzmocnienia wykonanego z kompozytu węglowego stwierdzono znaczne zmniejszenie poziomu naprężeń zredukowanych do około $20 \mathrm{MPa}$. 


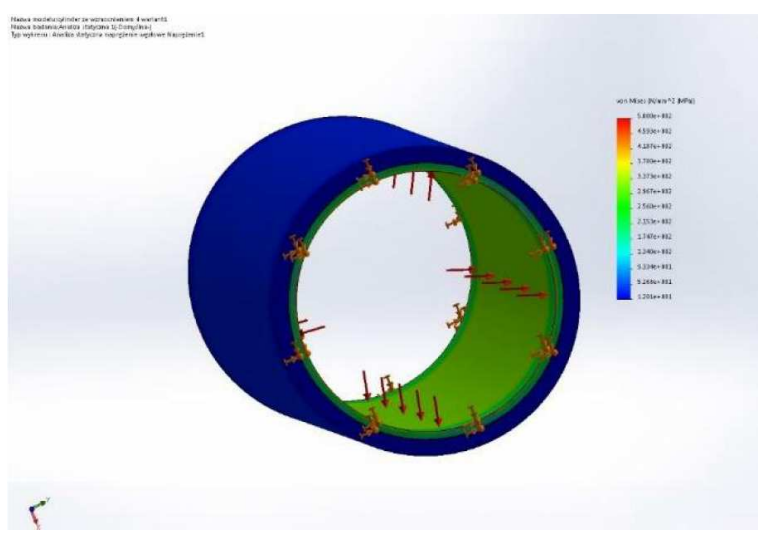

Rys. 8. Wykres naprężeń zredukowanych obliczonych wg hipotezy Hubera-Misesa dla modelu cylindra siłownika ze stopu 7075 i kompozytu węglowego CFRP

Na rysunku 9 przedstawiono wykres przemieszczeń dla modelu cylindra siłownika ze stopu 7075 ze wzmocnieniem w postaci kompozytu węglowego CFRP. Maksymalna wartość przemieszczenia wynosi około $0,07 \mathrm{~mm}$, natomiast części zewnętrznej nawet $0,12 \mathrm{~mm}$. Uzyskane wyniki mogą być związane z zadeklarowanym wciskiem o wartości $0,1 \mathrm{~mm}, \mathrm{tj} .0,05 \mathrm{~mm}$ na „stronę”. Zadeklarowanie wcisku ma na celu odzwierciedlenie obciążenia wstępnego zbrojenia kompozytu węglowego - tak jak w przypadku zbrojenia kompozytu typu UD „Parkera” nić węglowa lub aramidowa jest naciągana wstępnie.

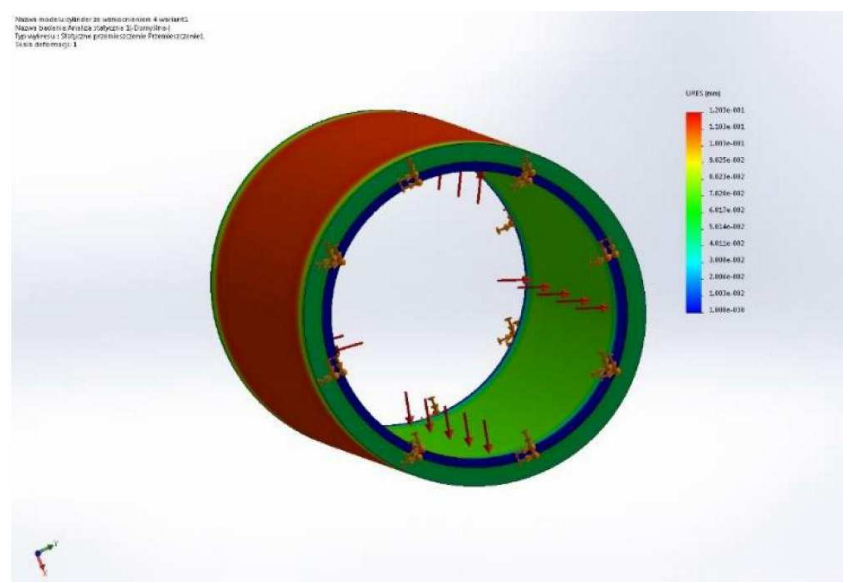

Rys. 9. Wykres przemieszczeń obliczonych dla tulei cylindra siłownika ze stopu 7075 i kompozytu węglowego CFRP

Na rysunku 10 przedstawiono wykres rozkładu współczynnika bezpieczeństwa FOS obliczonego dla modelu tulei cylindra siłownika ze stopu 7075 ze wzmocnieniem w postaci kompozytu węglowego CFRP. Najmniejsza wartość FOS wynosi około 1,1. W części powierzchni cylindrycznej bezpośrednio obciążonej ciśnieniem wartość współczynnika bezpieczeństwa FOS wynosi w przybliżeniu 1,60. Po powierzchni zewnętrznej cylindra wartość ta jest znacznie większa, FOS >6,0. Podsumowanie:

- Całkowita masa rozważanej tulei cylindra siłownika przy zastosowaniu wzmocnienia z materiału kompozytowego wynosi 49,38 g.

- Zastosowanie wzmocnienia z kompozytu węglowego powoduje zwiększenie współczynnika bezpieczeństwa z poziomu około FOS = 1,35 dla tulei duralowej bez wzmocnienia, do około FOS $=1,7, \mathrm{w}$ przypadku zastosowania wzmocnienia kompozytowego, czyli zwiększenie poziomu współczynnika bezpieczeństwa o około 35\% przy tej samej masie. 


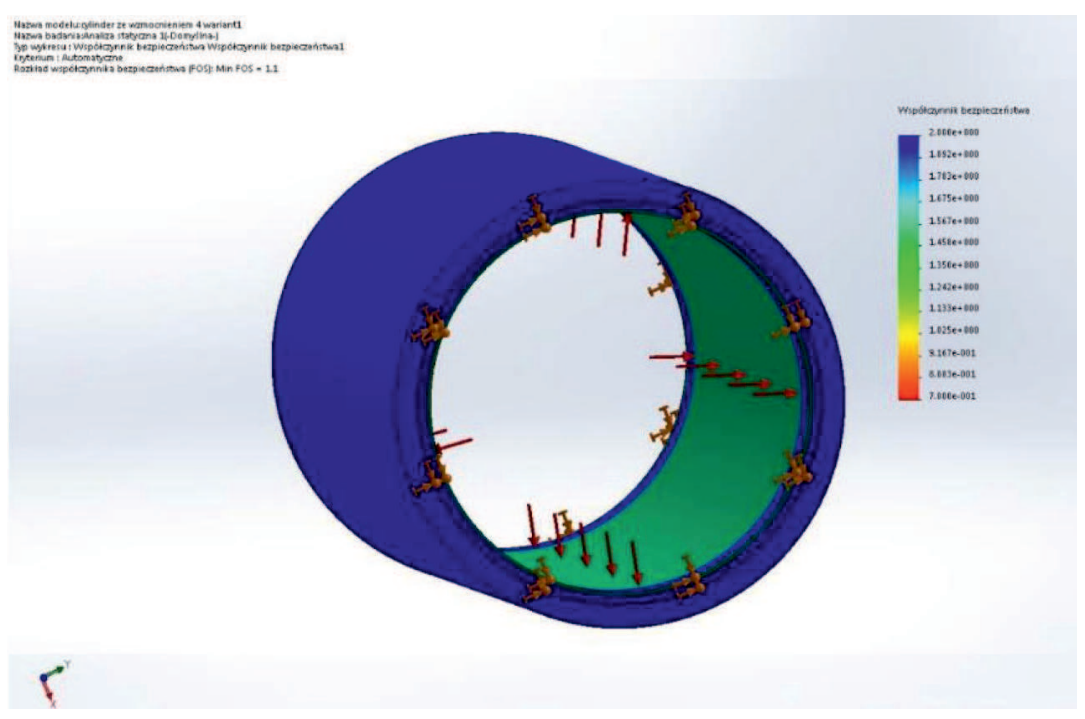

Rys. 10. Wykres rozkładu współczynnika bezpieczeństwa FOS obliczonego dla modelu tulei cylindra siłownika ze stopu 7075 i kompozytu węglowego CFRP

\section{Badania eksperymentalne}

Po wykonaniu prototypu siłownika SHDTLK wykonano badania w celu określenia jego podstawowych parametrów funkcjonalnych. Podstawowe badane parametry to: szczelność, skok, maksymalne ciśnienie pracy, minimalne ciśnienie pracy (dla siłownika nieobciążonego i dla siłownika obciążonego), prędkość wysuwu tłoczyska, maksymalna siła na tłoczysku dla ciśnienia nominalnego.

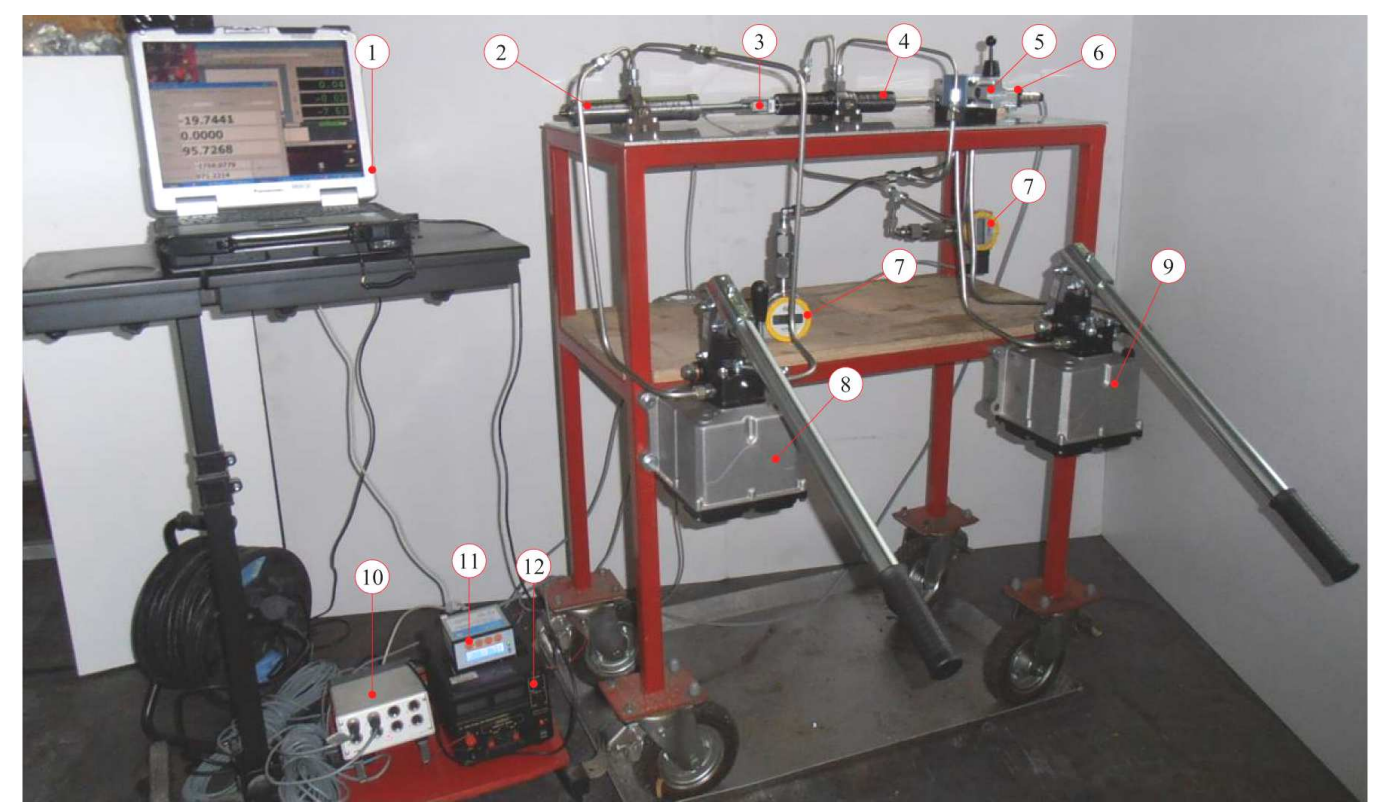

Rys. 11. Widok stanowiska do badania statycznego siłownika hydraulicznego, 1 - układ rejestracji danych pomiarowych, 2 - siłownik obciążający (SHDT nr 1), 3 - tensometryczny czujnik

siły K1505-10kN, 4 - siłownik badany (SHDTLK nr 1), 5 - zawór rozdzielający 4WMM5-E-12,

6 - potencjometr liniowy, 7 - czujnik ciśnienia PWXG, 8 - hydrauliczna pompa PMI 6LRV+P układu obciążenia, 9 - hydrauliczna pompa PMI 6LRV+P układu zasilania siłownika badanego,

10 - rejestrator MT-8, 11 - rejestrator MG-TAE1, 12 - zasilacz laboratoryjny 
Badania zostały zrealizowane w pracowni napędów płynowych ITWL na wcześniej zaprojektowanym i zbudowanym stanowisku badawczym (rys. 11).

Badania wykonano dla siłownika SHDTLK na wcześniej zaprojektowanym i zbudowanym stanowisku badawczym zaprezentowanym na rys. 10. Badania przeprowadzono zgodnie z zaproponowaną metodyką badawczą. Wyniki z kolejnych badań przeprowadzonych na siłowniku SHDTLK przedstawiono na rys. $12 \div 15$.

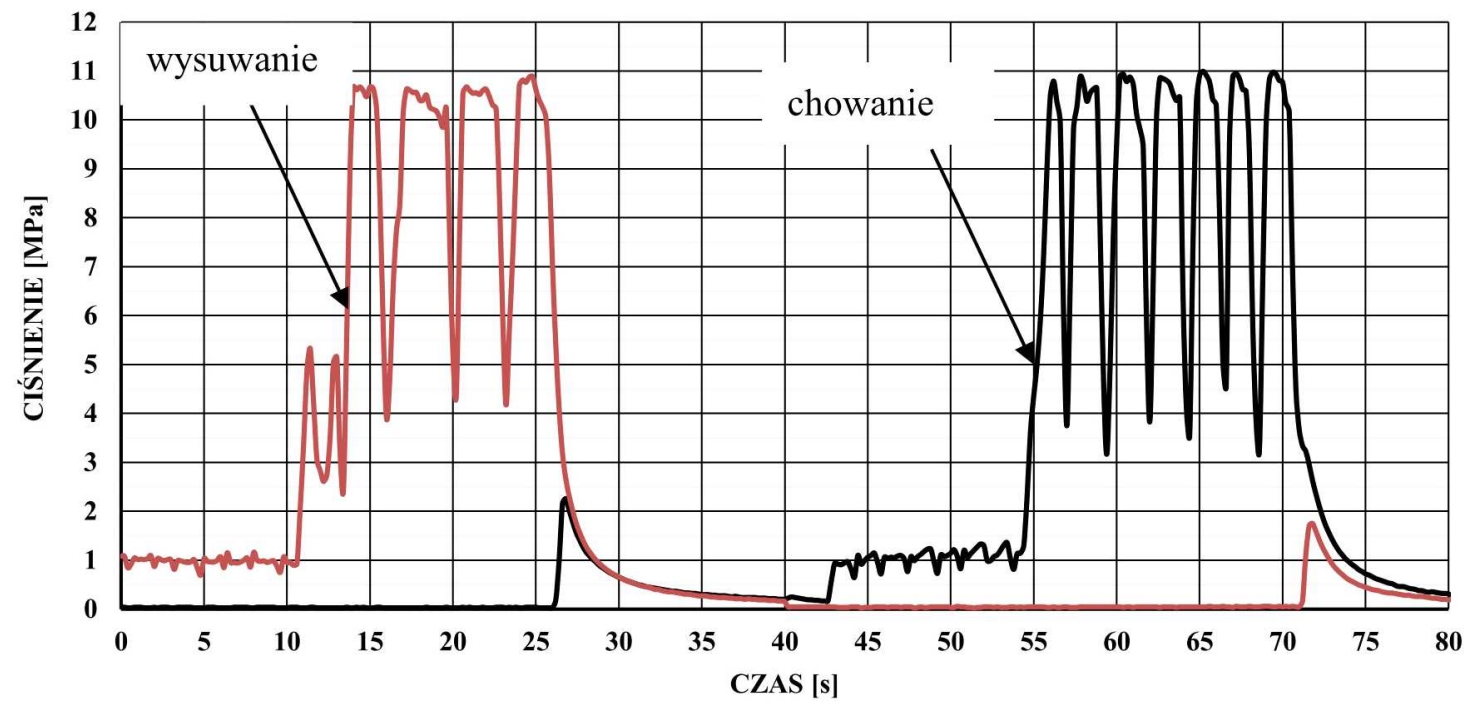

Rys. 12. Charakterystyka zmiany wartości ciśnienia przy wysuwaniu i chowaniu dla nieobciążonego tłoczyska siłownika SHDTLK nr 1 przy maksymalnym strumieniu zasilającym

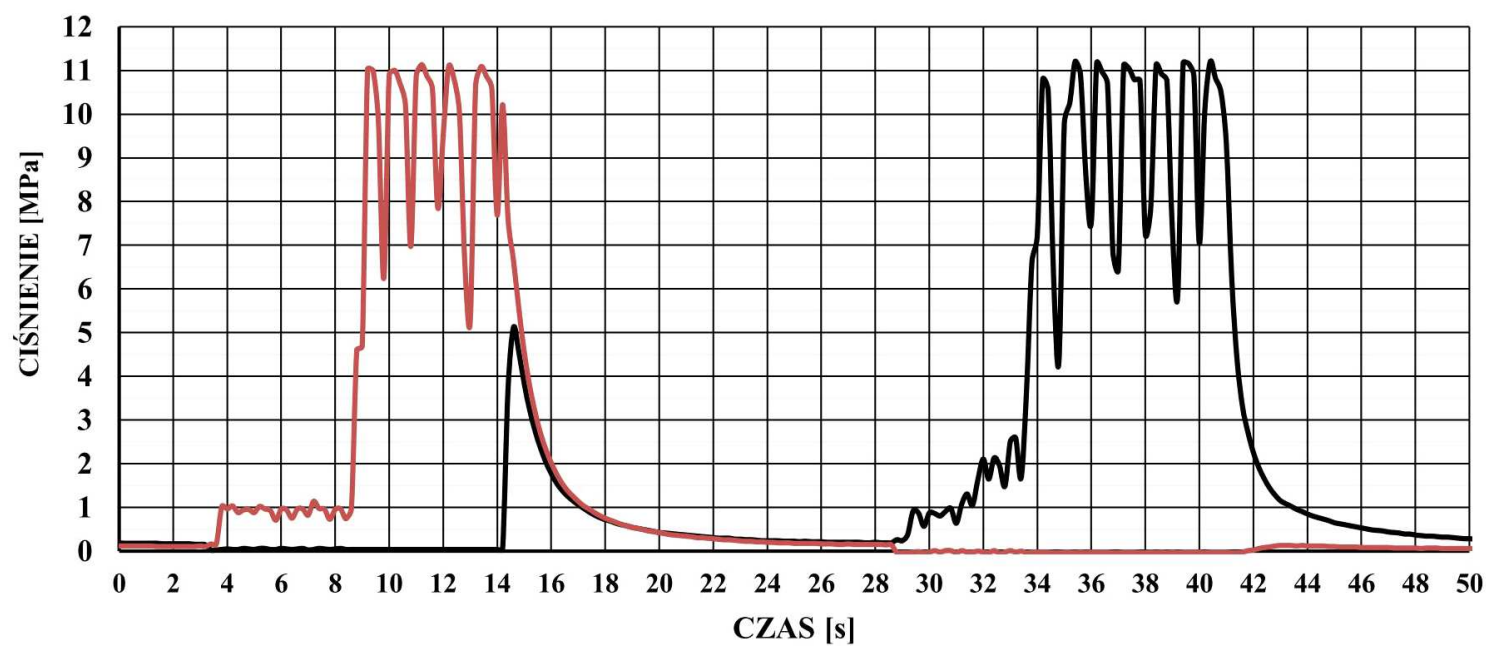

Rys. 13. Charakterystyka zmiany wartości ciśnienia przy wysuwaniu i chowaniu dla nieobciążonego tłoczyska siłownika SHDTLK nr 1 - badanie maksymalnego ciśnienia zasilania komory roboczej

\section{Podsumowanie}

Na podstawie opracowanego modelu bryłowego i opracowanej dokumentacji konstrukcyjnej wykonano siłownik hydrauliczny SHDTLK ze wzmocnieniem kompozytowym cylindra. Przeprowadzone badania potwierdziły założenia projektowe.

Opracowane rozwiązania technologiczne siłowników hydraulicznego potwierdziło, że możliwe jest znaczne obniżenie masy siłownika. Masa proponowanego siłownika, spełniającego założenia 


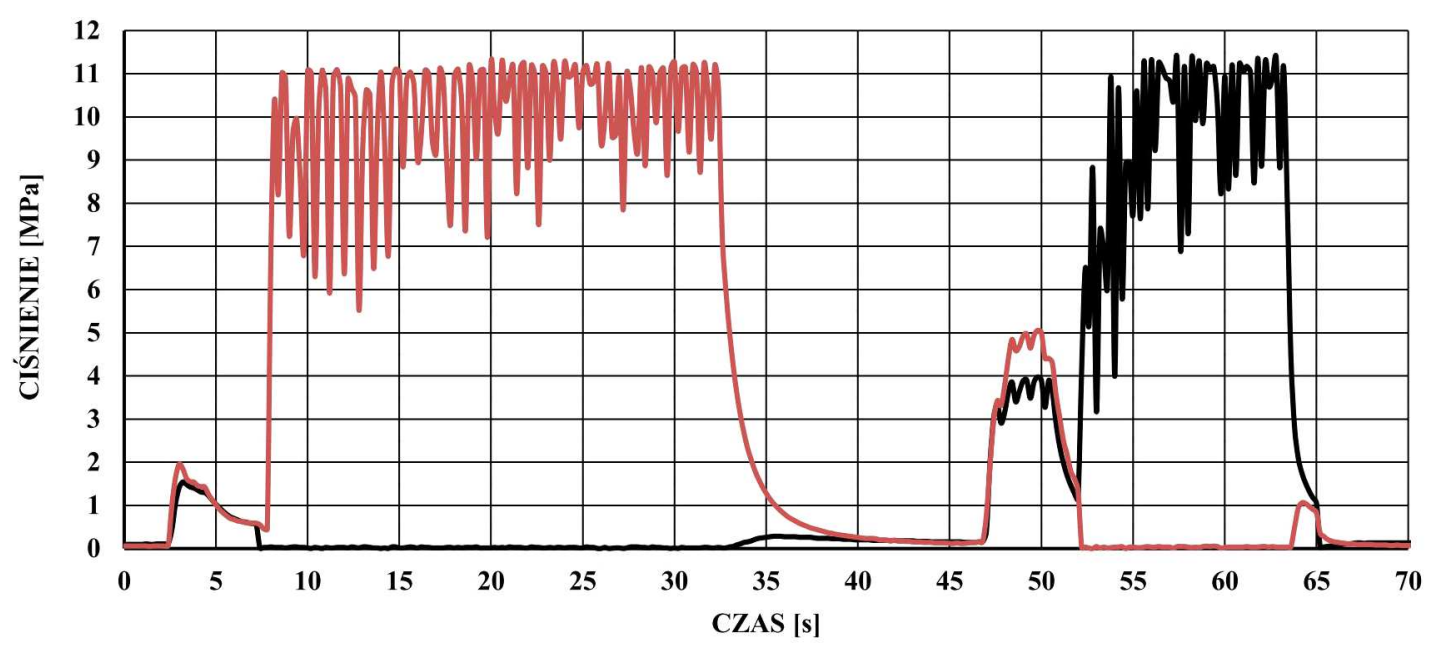

Rys. 14. Charakterystyka zmiany wartości ciśnienia przy wysuwaniu i chowaniu dla obciążonego tłoczyska siłownika SHDTLK nr 1 - badanie maksymalnej siły na tłoczysku

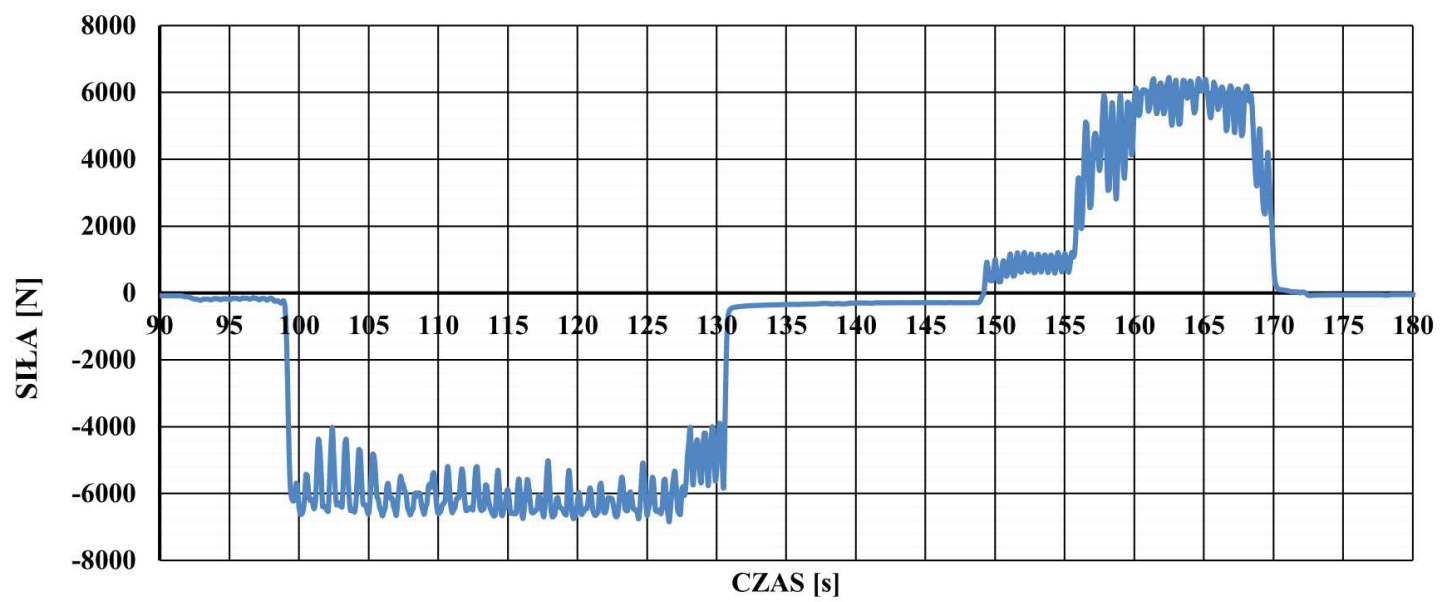

Rys. 15. Charakterystyka zmiany wartości siły na tłoczysku obciążonego siłownika SHDTLK przy wysuwaniu i chowaniu - badanie maksymalnej siły na tłoczysku

projektowe wynosi zaledwie $780 \mathrm{~g}$ (w wersji ze stopów lekkich i ze wzmocnieniem kompozytowym). Stosując stopy lekkie i wzmocnienia kompozytowe, możliwe jest obniżenie masy siłownika jeszcze o kilka do kilkunastu procent. Odnosząc się do masy zastosowanego siłownika w konstrukcji ILX27, która wynosi około $7 \mathrm{~kg}$, przy 4 sztukach na płatowcu, redukujemy $24 \mathrm{~kg}$.

Zastosowane wzmocnienia kompozytowego polepszyło własności mechaniczne oraz zredukowały masę siłownika w odniesieniu do wersji z tradycyjnych materiałów. Przeprowadzone badania własności siłownika potwierdziły porównywalny poziom parametrów funkcjonalnych siłownika ze wzmocnieniami kompozytowymi.

Realizacja przedmiotowej pracy pozwoliła opracować wersje siłownika hydraulicznego w oparciu o synteze istniejącej wiedzy na ten temat, z istotnym wkładem nowatorskich rozwiązań konstrukcyjnych, technologicznych i materiałowych. Stanowi również mocną bazę do opracowania rozwiązania konstrukcyjnego siłownika SHDTLK na wyższym poziomie gotowości technologicznej, jak również na implementację rozwiązania na rzeczywistych obiektach.

Opracowane rozwiązania umożliwia uzyskanie gęstości przenoszonej mocy na poziomie $4 \mathrm{~kW} / \mathrm{kg}$ i więcej. 


\section{Bibliografia}

1. Kotnis G., Budowa i eksploatacja układów hydraulicznych w maszynach, Wydawnictwo KaBe, Krosno, 2011

2. UŁAnowicz L., Analiza stabilności układu hydraulicznego wspomagania sterowania samolotem, Przeglad Mechaniczny, 11, 6, 18-24, PL ISSN 0033-2259

3. Stryczek S., Naped hydrostatyczny, WNT Warszawa, 2005

4. Szabelski K., Jancalewicz B., ŁucJaneK W. (Red.), Wstęp do konstrukcji śmigłowców, WKE Warszawa, 1995

5. NAwrat A., Modelowanie i sterowanie bezzałogowych obiektów latajacych, Wydawnictwo Politechniki Śląskiej, Gliwice, 2009

6. LIPSKI J., Napedy i sterowania hydrauliczne, WK€ Warszawa, 1977

7. Tomczyk J., Modele dynamiczne elementów i układów napędów hydrostatycznych, WNT Warszawa, 1999

8. Witkowski R., Budowa i pilotaż śmigłowców, WKŁ Warszawa, 1986

9. Baczewski K., Hebda M., Filtracja płynów eksploatacyjnych, MCNEMT Radom, 1991

10. UŁanowicz L., Badanie procesów destrukcyjnych w lotniczych napędach hydraulicznych w aspekcie ich trwałości, Wydawnictwo ITWL Warszawa, 2013

\section{Tests on a composite hydraulic actuator for a servomechanism that supports control of an unmanned helicopter}

This paper is devoted to developing an in-house technology and designing a hydraulic actuator for the control system of a light unmanned helicopter. The article is intended to present the issues associated with designing the hydraulic actuator for collective pitch control and cyclic pitch control of the helicopter rotor head and pitch control of the auxiliary rotor. The paper describes the in-house solution of the hydraulic actuator with a central power system. This actuator is designed as a part of an ongoing project for a light multi-purpose unmanned helicopter. The paper also suggests ways of reducing the mass of such a hydraulic actuator by applying modern composite techniques. The design works and results of our research on the prototype of the hydraulic actuator with composite reinforcements enabled us to formulate conclusions regarding the design process of such actuators, which are used, e.g. in light unmanned helicopters. 